\title{
Biomass and dynamics of Thalassia testudinum in the Mexican Caribbean: elucidating rhizome growth
}

\author{
Margarita E. Gallegos ${ }^{1}$, Martín Merino $^{2}$, Nuria Marbá $^{3}$, Carlos M. Duarte ${ }^{3}$ \\ ${ }^{\text {l} D e p a r t a m e n t o ~ d e ~ H i d r o b i o l o g i ́ a, ~ U n i v e r s i d a d ~ A u t o ́ n o m a ~ M e t r o p o l i t a n a ~-~ I z t a p a l a p a, ~ M i c h o a c a ́ n ~ y ~ P u r i ́ s i m a, ~ c o l . ~ V i c e n t i n a, ~}$ \\ AP 55-535, 09340 México, D.F., México \\ ${ }^{2}$ Instituto de Ciencias del Mar y Limnología, Universidad Nacional Autónoma de México, AP 70-305, \\ 04510 México, D.F., México \\ ${ }^{3}$ Centro de Estudios Avanzados de Blanes, CSIC, Camino de Santa Bárbara sn, E-17300 Blanes, Girona, Spain
}

\begin{abstract}
We report here data on biomass and dynamics of shoots and rhizomes of Thalassia testudinum in the Mexican Caribbean based, primarily, on aging of plant material. We found $T$ testudinum to be able to reach high biomass (> $1000 \mathrm{~g}$ dry $w \mathrm{~m}^{-2}$ ) and develop highly productive populations (1500 to $4500 \mathrm{~g}$ dry wt $\mathrm{m}^{-2}$ annually, of which $10 \%$ were allocated to the rhizomes) in the Mexican Caribbean. The plants appeared to grow slowly, as reflected in longer time intervals in between production of leaves and shoots, and slower rhizome elongation rates and leaf production rates than found in the past, possibly as a result of their low nutrient, particularly phosphorus, content. Calculated maximum shoot life spans ranged between 6 and 9 yr, shoot recruitment rates ranged from 0.02 to 0.07 In units per plastochrone interval (PI) and shoot mortality rate was substantial and averaged about $0.045 \mathrm{ln}$ units $\mathrm{PI}^{-1}$ Shoots turned over at ca $0.6 \mathrm{yr}^{-1}$, which also represents the rhizome turnover rate.
\end{abstract}

\section{INTRODUCTION}

Shallow areas of the Caribbean Sea are characterised by highly productive seagrass meadows, dominated by Thalassia testudinum Banks ex König (den Hartog 1970). Knowledge of the production of $T$. testudinum is, however, skewed towards populations along the coasts of Florida, USA (e.g. Zieman 1974, Kenworthy \& Thayer 1984, Zieman et al. 1989), and Caribbean Islands (Patriquin 1973, Buesa 1974, Williams 1988), and there is a need to extend these measurements to $T$. testudinum beds elsewhere in the Caribbean. Moreover, most of the available data on $T$. testudinum production refer to leaf growth, and there is a remarkable paucity of data on growth of $T$. testudinum rhizomes (cf. Duarte 1991). The scarcity of data should be attributable to the greater interest in aboveground production, for simple techniques to estimate growth of $T$. testudinum rhizomes have been available for about 2 decades (Patriquin 1973).
We report here data on biomass and dynamics of 3 different populations of Thalassia testudinum in the Mexican Caribbean, with emphasis on growth and dynamics of rhizomes, both vertical (i.e. short shoots) and horizontal. We used biomass measurements and plant dating techniques (Patriquin 1973) to elucidate shoot age structure and population dynamics. Our study of plant growth followed, therefore, a demographic approach, which, although not strictly equivalent to conventional (i.e. based on plant weight) growth analysis, yields comparable results and offers clear operational advantages (McGraw \& Garbutt 1990a, b). To compare these results with previous (based on weight) growth analyses, we converted our demographic estimates of plant growth to conventional (i.e. weight-based) units by combining the measured biomass of the different seagrass fractions with their (demographic-based) turnover times. 


\section{METHODS}

We sampled 3 different Thalassia testudinum populations around Cancún (about $21^{\circ} \mathrm{N}, 87^{\circ} \mathrm{W}$; Yucatán Península, México) subject to different degrees of anthropogenic disturbance. The first population was next to an undisturbed coral barrier-reef (reef population), the second grew in the reef-lagoon beach (reeflagoon population), influenced by the nearby town of Puerto Morelos, and the third grew in shallow, eutrophied Bojorquez Lagoon (Merino \& Otero 1991, Reyes \& Merino 1991). Previous studies, based on the identification of annual cycles in $T$. testudinum vertical shoot growth, estimated the annual leaf production rate of these populations to range from 17 leaves shoot ${ }^{-1} \mathrm{yr}^{-1}$ in the eutrophied lagoon and the barrier reef, to a minimum of 14 leaves shoot $\mathrm{yr}^{-1}$ in the reef-lagoon beach (N. Marbá, M. E. Gallegos, M. Merino, C. M. Duarte unpubl.). These estimates refer to annual means and are, therefore, not necessarily accurate at shorter time scales. Because these 3 populations differ in aspects other than the anthropogenic influence they are subject to (e.g. exposure to mechanical stress; Marbá et al. unpubl.), our goal in studying these 3 populations was to increase the generality of our findings by encompassing a range of conditions, and we do not attempt to attribute observed differences to anthropogenic disturbance.

Shoots and rhizomes of Thalassia testudinum were collected in 12 to 24 (depending on plant density) replicated cores (20.5 or $28 \mathrm{~cm}$ internal diameter) pushed to a depth of about $40 \mathrm{~cm}$ in the sediment (coarse carbonated sand), thereby containing all living rhizomes. Sediment was carefully rinsed off the samples to prevent shoots from loosing their connection to the rhizomes, which was needed to estimate shoot age. We then counted all of the living shoots and the internodes of the rhizome pieces in the sample, counted the number and measured the length and width of all entire leaves in each shoot, and measured the length (from their insertion in the rhizome to the growing meristem) of the vertical rhizomes in the short shoots. The length of the rhizome pieces in between consecutive shoots was also measured and the number of internodes counted to be used to estimate rhizome growth. We then estimated the age of all living (i.e. bearing green leaves) and dead (i.e. devoid of green leaves) shoots that maintained their connection to the rhizome ( $>80 \%$ of the shoots) as the sum of leaf scars and standing leaves (Patriquin 1973). Dead shoots were dated only if they ended in a rounded tip, indicating that the shoot was not broken. The resulting age-time units correspond to the average time interval between the initiation of 2 successive leaves on a shoot, refered to as plastochrone interval (PI; Erickson
\& Michelini 1957, Brouns 1985a, b). Plastochrone intervals represent indirect estimates of time, which, although subject to seasonal variability, provide accurate estimates of time at interannual time scales (cf. Brouns 1985a, b). A subsample of the shoots and rhizomes in each sample was dried overnight at $70^{\circ} \mathrm{C}$ to calculate average dry weights of these modules, and leaf nutrient ( $\mathrm{C}, \mathrm{N}$ and $\mathrm{P}$ ) contents were measured in duplicate subsamples (coefficient of variation of replicate samples $<2 \%$ ) using a Carlo-Erba autoanalyzer for $\mathrm{C}$ and $\mathrm{N}$ contents, and a colorimetric method, following wet acid digestion, for $\mathrm{P}$ determinations (Koroleff 1983).

Shoot age structure was represented by the age of both living and dead shoots. Although the average age of living shoots represents the overall age of the shoot population, it does overestimate their average life expectancy, which is best represented by the age at death. The age difference between consecutive shoots along the rhizome was used to estimate the time interval (as plastochrone intervals) in between the appearance of consecutive shoots (hereafter termed shoot plastochrone interval), and the rate of rhizome elongation (i.e. the ratio of the length of the rhizome piece to the age difference; cf. Patriquin 1973). The ratio of the number of rhizome internodes in between consecutive shoots to the age difference between them was used to estimate the rate of appearance of rhizome internodes (Patriquin 1973). Similarly the growth rate of vertical rhizomes was estimated as the slope of a linear regression equation between shoot length of vertical rhizomes $(y)$ and their age (i.e. number of leaf scars, $x$ ). All time estimates based on leaf plastochrone intervals (i.e. shoot age, rhizome extension rate, shoot appearance rate) were converted into natural time by using the annual mean duration of the leaf plastochrone interval $(26.1,21.7$ and $21.3 \mathrm{~d}$ for the reeflagoon beach, barrier reef and eutrophied lagoon respectively) from Marbá et al. (unpubl.). Shoot mortality $\left(K\right.$, in natural logarithm units time ${ }^{-1}$; cf. Duarte \& Sand-Jensen 1990b) was calculated from the age distribution of the shoots by fitting the equation

$$
N_{t}=N_{0} e^{-K t}
$$

which describes the exponential decline in shoot number $(N)$ in increasingly old age classes with time $(t)$ from the onset on mortality $(t=0)$.

\section{RESULTS AND DISCUSSION}

All populations had leaves depleted in phosphorus relative to other nutrients (Table 1), suggesting that phosphorus availability probably limits their growth (cf. Duarte 1990), and consistent with the hypothesis 
that carbonated sediments support phosphorus-limited seagrass meadows (Short 1987). Although the leaves of plants in the eutrophied lagoon had higher nitrogen concentrations than those of other populations, they were the most depleted in phosphorus relative to carbon and nitrogen (Table 1), suggesting that their growth may have been phosphorus limited despite substantial nutrient loading to the lagoon. The population in the eutrophied lagoon was denser and had greater shoot biomass than the reef populations (Table 1), which also had shoots bearing fewer and shorter, leaves. Rhizome biomass was also greater at the eutrophied lagoon, because of a tendency to have more and longer internodes there than those at the reef populations (Table 1), although this difference was much smaller than that in shoot biomass.

We observed a close relationship between rhizome biomass and shoot density, and between shoot density and shoot biomass (Fig. 1), indicative of a close dependence of shoot density and biomass on rhizome development. Leaf turnover, estimated as the ratio between the annual leaf production rate and the average number of leaves per shoot, was found to be lowest at the eutrophied lagoon (Table 1). The rate of rhizome growth, measured as the horizontal elongation rate and the rate of appearance of rhizome internodes (i.e. rhizome PI), tended to be greater, but not significantly so, in the reef meadow (Table 1). The rate of appearance of new shoots (i.e. shoot PI, Table 1) was, however, significantly lower at the reef-lagoon meadow $\left(<2\right.$ shoots rhizome apex ${ }^{-1}$ $\left.\mathrm{yr}^{-1}\right)$ than those at the reef and the eutrophied lagoon (ca 4 shoots rhizome apex ${ }^{-1} \mathrm{yr}^{-1}$ ). The regression equation describing the relationship between the length (in $\mathrm{mm}$ ) of the vertical rhizomes (i.e. short shoots) and their age (in leaf PIs) (Fig. 2),

log shoot length $=-0.06+1.03 \log$ shoot age

$\mathrm{R}^{2}=0.80, \mathrm{~N}=364, F=1450, \mathrm{p}<0.0001$

indicated that the rate of vertical growth of short shoots did not change significantly as shoots became older (i.e. $\mathrm{H}_{0}$ : slope $=1$; $t$-test, $\mathrm{p}>0.50$ ). Moreover, analysis of covariance showed the rate of vertical growth of short shoots to be similar, at about $1 \mathrm{~mm}$ per leaf produced, for all populations examined (ANCOVA, $p<0.0001$; Fig. 2). Substantially faster (up to 10 -fold) vertical growths may occur, however, in response to burial (Marbá et al. unpubl.). The slope of this relationship (1 mm per leaf produced) indicates a vertical growth of the rhizomes of ca 15 to $20 \mathrm{~mm} \mathrm{yr}^{-1}$, which, multiplied by the density of short shoots ( 500 to 1000 shoots $\mathrm{m}^{-2}$ )

Table 1. Thalassia testudinum. Summary of the biomass and dynamics of the seagrass populations studied, represented by an undisturbed meadow growing next to a barrier reef, a population subject to moderate anthropogenic disturbance (lagoon-reef beach), and a population growing in a eutrophied lagoon (Bojorquez Lagoon). Mean \pm SE reported, and F-values and probability values from 1-way ANOVA to test for significant differences among the populations are reported for all variables, except for those calculated from other variables. ': populations that differed significantly from the others (HSD Tukey multiple comparisons test); NS: not significant

\begin{tabular}{|c|c|c|c|c|}
\hline Variable & Reef & Lagoon-reef & Bojorquez L. & $F$-value \\
\hline Shoot biomass ( $\mathrm{g}$ dry wt $\mathrm{m}^{-2}$ ) & $222 \pm 28$ & $222 \pm 22$ & $693 \pm 105^{\circ}$ & $28(<0.0001)$ \\
\hline Shoot density (shoots $\mathrm{m}^{-2}$ ) & $480 \pm 59$ & $510 \pm 54$ & $1222 \pm 160^{\circ}$ & $21(<0.0001)$ \\
\hline Leaf length (mm shoot $\left.{ }^{-1}\right)$ & $122.2 \pm 9.3$ & $109 \pm 5.0$ & $256 \pm 23.3^{\circ}$ & $51(<0.0001)$ \\
\hline Leaves shoot ${ }^{-1}$ & $2.3 \pm 0.07$ & $2.3 \pm 0.05$ & $2.97 \pm 0.07$ & $34.5(<0.0001)$ \\
\hline Rhizome biomass ( $\mathrm{g}$ dry wt $\mathrm{m}^{-2}$ ) & $307 \pm 41$ & $261 \pm 17$ & $467 \pm 47^{\circ}$ & $6.5(<0.001)$ \\
\hline Internodal length (mm) & $5.5 \pm 0.2$ & $4.8 \pm 0.14$ & $5.9 \pm 0.21^{\bullet}$ & $9.3(<0.001)$ \\
\hline Internode density (internodes $\mathrm{m}^{-2}$ ) & $12800 \pm 1700$ & $15400 \pm 1000$ & $24300 \pm 2500^{\circ}$ & $10(<0.001)$ \\
\hline Total shoot biomass turnover $\left(\mathrm{yr}^{-1}\right)$ & 7.3 & 6.1 & 5.8 & - \\
\hline Rhizome PI (d internode ${ }^{-1}$ ) & 3.7 & 5.5 & 5.4 & - \\
\hline 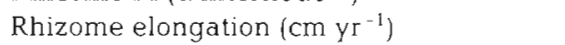 & $35 \pm 8.9$ & $22.3 \pm 3.6$ & $24.4 \pm 2.5$ & $1.6(\mathrm{NS})$ \\
\hline Shoot PI (d shoot ${ }^{-1}$ ) & $84 \pm 17$ & $193 \pm 44$ & $81 \pm 8.5$ & $4.1(<0.05)$ \\
\hline Shoot age (leaf PI) & $27.7 \pm 1.3^{\circ}$ & $38.9 \pm 1.4^{\circ}$ & $17.2 \pm 1.0^{\circ}$ & $65(<0.0001)$ \\
\hline Shoot recruitment (In units $\mathrm{PI}^{-1}$ ) & 0.024 & 0.018 & 0.069 & - \\
\hline Average shoot life expectancy (leaf PI) & $20.9 \pm 1.7$ & $21.2 \pm 1.4$ & $16.8 \pm 1.5$ & 1.6 (NS) \\
\hline Maximum shoot life expectancy & $116 \mathrm{PI}(7 \mathrm{y})$ & 134 PI $(9.5 y)$ & 99 PI $(6 y)$ & - \\
\hline Shoot turnover $\left(\mathrm{yr}^{-1}\right)(\approx$ rhizome turnover $)$ & 0.48 & 0.66 & 0.70 & - \\
\hline Rhizome internodes in between shoots & $13.1 \pm 0.4$ & $15.4 \pm 0.6^{\circ}$ & $11.6 \pm 0.7$ & $9.3(<0.001)$ \\
\hline Rhizome length in between shoots (mm) & $69.3 \pm 2.2$ & $71.2 \pm 2.5$ & $58.4 \pm 2.6^{\circ}$ & $7.9(<0.001)$ \\
\hline Shoot mortality rate (In units $\mathrm{PI}^{-1}$ ) & $0.046 \pm 0.004$ & $0.053 \pm 0.008$ & $0.040 \pm 0.007$ & NS \\
\hline Carbon (\% dry wt) & 32.77 & 34.65 & 32.79 & - \\
\hline Nitrogen (\% dry wt) & 2.18 & 1.78 & 2.72 & - \\
\hline Phosphorus (\% dry wt) & 0.180 & 0.147 & 0.139 & - \\
\hline$C: N: P$ (atoms) & $516: 29: 1$ & $669: 29: 1$ & $669: 47 \cdot 1$ & - \\
\hline
\end{tabular}



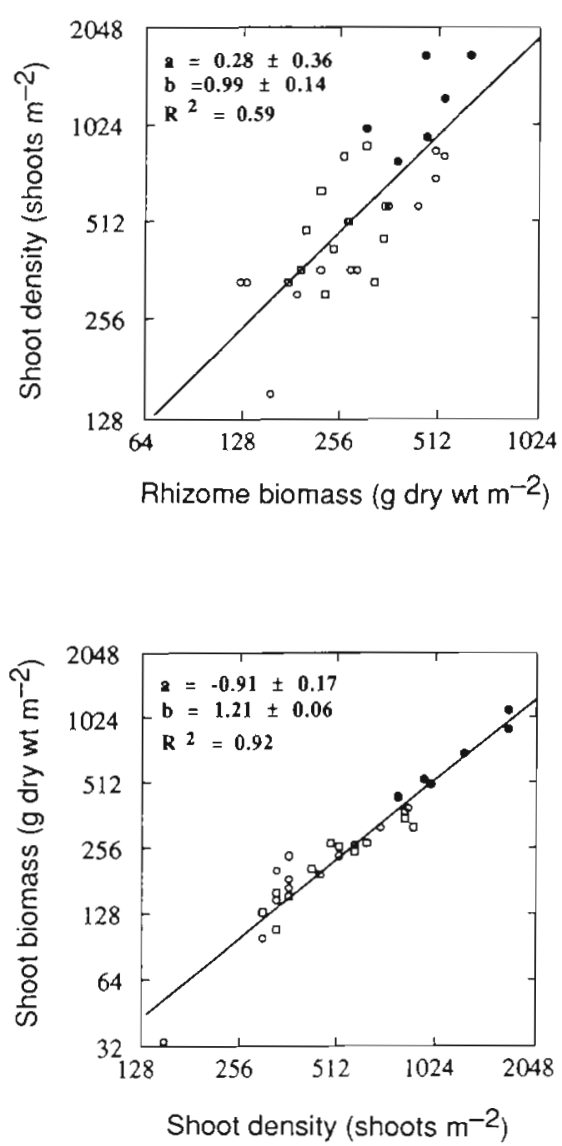

Fig. 1. Thalassia testudinum. Relationship between rhizome biomass and shoot density, and between shoot density and shoot biomass of seagrass in the reef meadow (o), Bojorquez Lagoon $(\bullet)$, and reef-lagoon beach $(0)$. Relationships are described by the regression coefficients $( \pm S E$ ) of the fitted equation $y=a X^{b}$, and the coefficient of determination $\left(\mathrm{R}^{2}\right)$

represents between 7.5 and $20 \mathrm{~m}$ of vertical rhizome produced $\mathrm{m}^{-2} \mathrm{yr}^{-1}$. These figures indicate that vertical growth must represent a sizeable fraction of the biomass produced.

Examination of the age structure of living shoots showed an increase in the abundance of short shoots $<1$ yr, which indicates that recruitment was not completed for the present year, and a tendency towards a decline in the abundance of older shoots (Fig. 3), indicative of shoot mortality. The decline in shoot abundance with shoot age was particularly evident for the Bojorquez Lagoon population (Fig. 3), which had, on the average, the youngest shoots (Table 1). These data allowed estimation of recruitment rates, which ranged from 0.02 to $0.07 \ln$ units $\mathrm{PI}^{-1}$ in the reef populations and the eutrophied lagoon, respectively (Table 1). Because the mean age of living shoots overestimates overall shoot life expectancy, we used the age-at-death of dead shoots to better estimate this. The cores collected included large numbers of dead

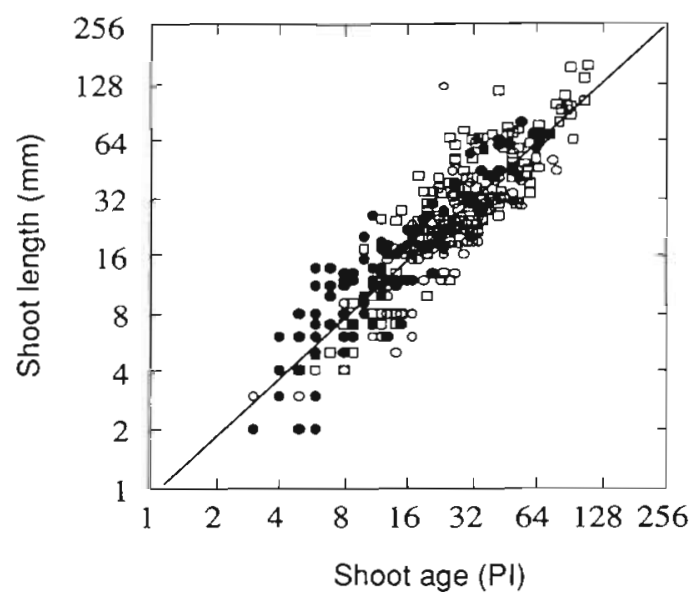

Fig. 2. Thalassia testudinum. The relationship between length and age of vertical seagrass shoots in the reef meadow $(0)$, Bojorquez lagoon $(\bullet)$, and reef-lagoon beach $(\square)$

shoots, which lacked standing leaves and ended on a rounded tip resulting from meristem death. Dead shoots outnumbered living shoots in the samples, the number of dead shoots which could be aged (i.e. maintained the connection to the rhizome) alone being larger than that of living shoots. Most shoots died at $\mathrm{ca}$ 20 PI (i.e. the average shoot life expectancy), and the average number of leaves produced at death did not differ significantly among shoots of different populations (Table 1). Yet, the longer plastochrone intervals of the reef population imply that their shoots had somewhat longer life expectancies (in days) than those of the remaining populations.

The distribution of shoot age at death (Fig. 3) revealed a clear exponential decline in shoot abundance with increasing shoot age for all 3 populations, thereby allowing accurate calculation of shoot mortality rates compared to those calculated from the distribution of living shoots (e.g. Duarte \& Sand-Jensen 1990b), which yield biased estimates if shoot recruitment varies substantially among years. The mortality rates calculated from the distribution of shoot age at death averaged about 0.045 ln units $\mathrm{PI}^{-1}$ (Table 1), similar to the magnitude of calculated recruitment rates (Table 1), and did not differ significantly among populations ( $t$-test, $p>0.10$ ). Our findings indicate that the populations sampled experience essentially similar mortality rates despite differing significantly in shoot age structure (Table 1), which can only be accounted for if recruitment rates varied during the life of the population, increasing in the eutrophied lagoon and decreasing in the reef populations.

The oldest shoots encountered (whether dead or living) had ages between 6 and $9 \mathrm{yr}$, in agreement with the longevity of 7 yr reported for Thalassia testudinum in the Mississippi, USA, area by Eleuterios (1987). For 
Living shoots
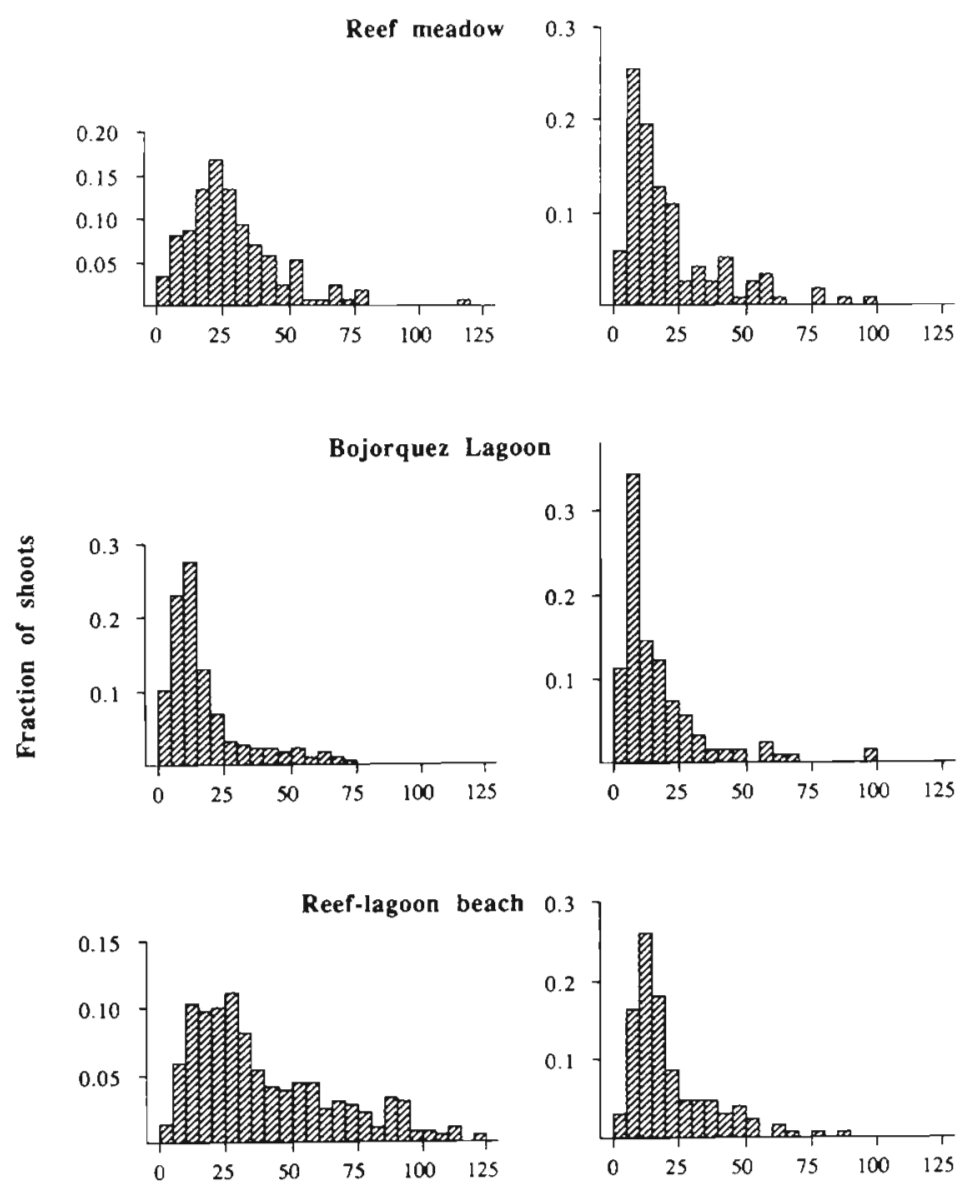

Shoot age (PI)

Fig. 3. Thalassia testudinum. The age distribution of living and dead seagrass shoots in the populations examined

the populations to remain stable, the turnover time of leaf-bearing rhizomes (i.e. short shoots), which is equivalent to the turnover time of shoot density, should be of the same order as their average life expectancy, (i.e. ca $0.6 \mathrm{yr}^{-1}$, Table 1). Moreover, recruitment of short shoots should be closely linked to rhizome development (Fig. 1) because the production of new shoots requires, on the average, a fixed investment in rhizome growth, as reflected in the rather uniform number of internodes and length of rhizome produced in between 2 consecutive shoots (Table 1 ) and the close relationship between rhizome biomass and shoot density (Fig. 1). Thus, turnover rates of vertical (i.e. short shoots) and horizontal rhizomes are expected to be similar (i.e. about $0.6 \mathrm{yr}^{-1}$, Table 1).

The annual biomass production of the populations can be approximated from our (demographic-based) estimates of leaf and rhizome turnover times (Table 1) by multiplying these by the biomass of the different compartments. These calculations indicate that the Thalassia testudinum populations examined should produce ca 1500 to $4500 \mathrm{~g}$ dry wt $\mathrm{m}^{-2}$ annually, of which $10 \%$ represent rhizome production, similar to the $15 \%$ reported, based on short-term measurements, by Patriquin (1973). The leaf production calculated represents annual shoot production rates in excess of $6 \mathrm{~g}$ dry wt $\mathrm{m}^{-2} \mathrm{~d}^{-1}$, corresponding to leaf turnover rates of about $1.8 \% \mathrm{~d}^{-1}$ (Table 1). Rhizome growth was slow, as reflected in long time intervals in between production of shoots and low rhizome elongation rates compared to average values for $T$. testudinum published in the past (Duarte 1991). Yet, $T$. testudinum may produce $>30$ leaves shoot ${ }^{-1} \mathrm{yr}^{-1}$ in the Mexican Caribbean (Marbá et al. unpubl.), compared to $<20$ leaves shoot ${ }^{-1} \mathrm{yr}^{-1} \mathrm{ob}-$ served in the populations examined here (Table 1), if exposed to high burial, and associated high nutrient supply (Marbá et al. unpubl.).

The results presented showed Thalassia testudinum to be able to develop highly productive populations on the mostly oligotrophic Mexican Caribbean coast. Both the biomass and shoot production measured were within the average values reported for this species (Stevenson 1988) (Table 2. Fig. 4), but exceeded previously reported values for the zone (Nugent et al. 1978, Tomasko \& Lapointe 1991) (Table 2). Standing biomass and daily leaf production of T. testudinum were observed to vary greatly (>100-fold) over its distributional area (Table 2, Fig. 4 ), yet leaf turnover rates vary only about 5-fold (Table 2, Fig. 4). This suggests that differences in areal daily leaf production should be largely dependent on differences in standing biomass (Duarte 1989), rather than differences in productivity of individual shoots. This was confirmed by the fact that $88 \%$ of the variance in reported areal daily leaf production of $T$. testudinum productivity could be accounted for by differences in standing biomass (Fig. 4). Thus, T. testudinum standing biomass is the single most important factor accounting for differences in areal leaf production, as observed in Florida Bay by Zieman et al. (1989). Standing biomass appears, in turn, to be closely controlled by nutrient, particularly $P$, availability (Fourqurean et al. 1992). The suggestion that $P$ availability may also control $T$. testudinum standing biomass in the Mexican Caribbean populations we examined is supported by the agreement between 
Table 2. Thalassia testudinum. Biomass ( $\mathrm{g}$ dry $w \mathrm{t} \mathrm{m}^{-2}$ ); productivity ( $\mathrm{g}$ dry $w \mathrm{w} \mathrm{m}^{-2} \mathrm{~d}^{-1}$ ) and turnover (in $\% \mathrm{~d}^{-1}$ in parentheses) of different seagrass meadows. Values represent the range midpoint and average values for data reported as ranges or studies involving multiple stations, respectively. Control values reported when the work involved experimental manipulation of the seagrass bed. L: leaves; R: rhizome

\begin{tabular}{|c|c|c|c|c|}
\hline Location & Plant part & Biomass & Production & Source \\
\hline Cuba & $\mathrm{L}$ & $517 \pm 180$ & $\begin{array}{c}4.9 \pm 0.44 \\
\left(1.2 \pm 0.18 \% \mathrm{~d}^{-1}\right)\end{array}$ & Buesa (1974) \\
\hline Barbados & $\begin{array}{l}\mathrm{L} \\
\mathrm{R}\end{array}$ & 1805 & $\begin{array}{c}6.5\left(3.4 \% \mathrm{~d}^{-1}\right) \\
1.04\end{array}$ & Patriquin (1973) \\
\hline Bermuda & $\begin{array}{l}\mathrm{L} \\
\mathrm{R}\end{array}$ & 4400 & $\begin{array}{l}16.5 \\
2.02\end{array}$ & Patriquin (1973) \\
\hline Florida (USA) & $\mathrm{R}$ & 1552 & & Kenworthy \& Thayer (1984) \\
\hline Florida (USA) & L & $65.2 \pm 5.9$ & $1.95 \pm 0.12\left(2.99 \% \mathrm{~d}^{-1}\right)$ & Zieman $(1975)$ \\
\hline Virgin Islands (USA) & $\begin{array}{l}\mathrm{L} \\
\mathrm{R}\end{array}$ & $\begin{array}{c}207 \\
1092\end{array}$ & $1.4\left(0.55 \% \mathrm{~d}^{-1}\right)$ & Williams (1987) \\
\hline Florida (USA) & $\mathrm{L}$ & & $\left(1.3 \% \mathrm{~d}^{-1}\right)$ & Barber \& Behrens (1985) \\
\hline Puerto Rico & $\mathrm{L}$ & 450 & & Burkholder et al. (1959) \\
\hline Florida (USA) & $L$ & 830 & & Jones (1968) \\
\hline Florida (USA) & $\mathrm{L}$ & & $2.09 \pm 0.41$ & Thorhaug \& Roessler (1977) \\
\hline Texas (USA) & $\mathrm{L}$ & 373 & & Odum (1963) \\
\hline Florida (USA) & $\mathrm{L}$ & 700 & & Bauersfeld et al. (1969) \\
\hline Veracruz (México) & $\mathrm{L}$ & 353 & & Lot-Helgueras (1971) \\
\hline Cuba & L & 340 & & Buesa $(1972)$ \\
\hline Florida (USA) & $\mathrm{L}$ & & 5 & Wood et al. (1969) \\
\hline Florida (USA) & $\begin{array}{l}\mathrm{L} \\
\mathrm{R}\end{array}$ & $\begin{array}{l}86.8 \pm 2.7 \\
793 \pm 66\end{array}$ & $\begin{array}{c}1.84 \pm 0.43 \\
\left(2.01 \% \mathrm{~d}^{-1}\right)\end{array}$ & Powell et al. (1989) \\
\hline Bahamas & $\mathrm{L}$ & 200 & $3.23\left(1.6 \% \mathrm{~d}^{-1}\right)$ & Capone et al. (1979) \\
\hline Florida (USA) & L & $46.7 \pm 8.7$ & $0.88 \pm 0.22\left(1.84 \pm 0.35 \% \mathrm{~d}^{-1}\right)$ & Tomasko \& Lapointe (1991) \\
\hline Belize & L & $43.2 \pm 13.4$ & $0.85 \pm 0.18\left(2.56 \pm 0.11 \% \mathrm{~d}^{-1}\right)$ & Tomasko \& Lapointe (1991) \\
\hline Florida (USA) & L & $49.5 \pm 9.8$ & $0.97 \pm 0.19\left(2.19 \pm 0.12 \% \mathrm{~d}^{-1}\right)$ & Zieman et al. (1989) \\
\hline Terminos L. (México) & $\begin{array}{l}\mathrm{L} \\
\mathrm{R}\end{array}$ & $205 \pm 28.7$ & $\begin{array}{l}6.57 \pm 1.48 \\
\left(3.2 \% \mathrm{~d}^{-1}\right)\end{array}$ & Day et al. (1982) \\
\hline Florida (USA) & $\begin{array}{l}\mathrm{L} \\
\mathrm{L}\end{array}$ & $\begin{array}{c}905 \\
379 \pm 157\end{array}$ & $\begin{array}{c}4.55\left(0.53 \% \mathrm{~d}^{-1}\right) \\
6.38 \pm 2.3\left(1.8 \pm 0.1 \% \mathrm{~d}^{-1}\right)\end{array}$ & Bittaker \& Iverson (1976) \\
\hline Cancún (México) & $\mathrm{R}$ & $345 \pm 62$ & $0.59 \pm 0.15\left(0.17 \pm 0.02 \% \mathrm{~d}^{-1}\right)$ & This study \\
\hline
\end{tabular}

observed average standing crop (345 g dry wt $\mathrm{m}^{-2}$ Table 2) and that predicted $\left(249 \pm 147 \mathrm{~g}\right.$ dry wt $\left.\mathrm{m}^{-2}\right)$ from the average leaf $C$ : $P$ ratio of their leaves (i.e. 618 , Table 1) using the relationship between leaf $C$ : $P$ ratio and standing crop developed by Fourqurean $f$ t al. (1992) for Florida Bay.

The age structure of the populations (Fig 3) allowed calculation of shoot recruitment and mortality rates (Table 1), and turnover rates of vertical rhizomes (Table 1), which were indicative, in turn, of those of horizontal rhizomes. These results demonstrated a close agreement between mortality and recruitment rates, as observed for Cymodocea nodosa in the past (Duarte \& Sand-Jensen 1990a) and suggested the existence of interannual changes in shoot recruitment, consistent with the greater recruitment rates compared to mortality rates observed in the eutrophied lagoon (Table 1).

That shoots of Thalassia testudinum can be easily aged has been known for about 2 decades (Patriquin 1973, Durako \& Moffler 1987, Cox \& Tomlinson 1988), yet, only recently has this technique been used to examine reproductive effort (Cox \& Tomlinson 1988, Gallegos et al. 1992) and reconstruct interannual changes in leaf production and vertical growth (Marbá et al. unpubl.) of $T$. testudinum shoots. The results presented here add to these demonstrations of the great potential of aging techniques to reliably examine the dynamics of $T$. testudinum and other species [e.g. Posidonia oceanica, Pergent \& Pergent-Martini (1990); Cymodocea nodosa, Duarte \& Sand-Jensen (1990a, b)], and suggest that the path pointed out by Patriquin (1973) leads to a promising scientific journey. These methods provide convenient, although less accurate, alternatives to marking techniques (e.g. Zieman 1974) in areas where the recurrent visits required by marking techniques are difficult. These techniques should, therefore, help to expand our knowledge of seagrass dynamics to remote areas.

Acknowledgements. This project was funded by a grant of the Spanish programme of Cooperation with Latin America 


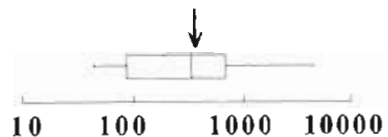

$10 \quad 100 \quad 1000 \quad 10000$

Biomass ( $g$ dry wt $\mathrm{m}^{-2}$ )
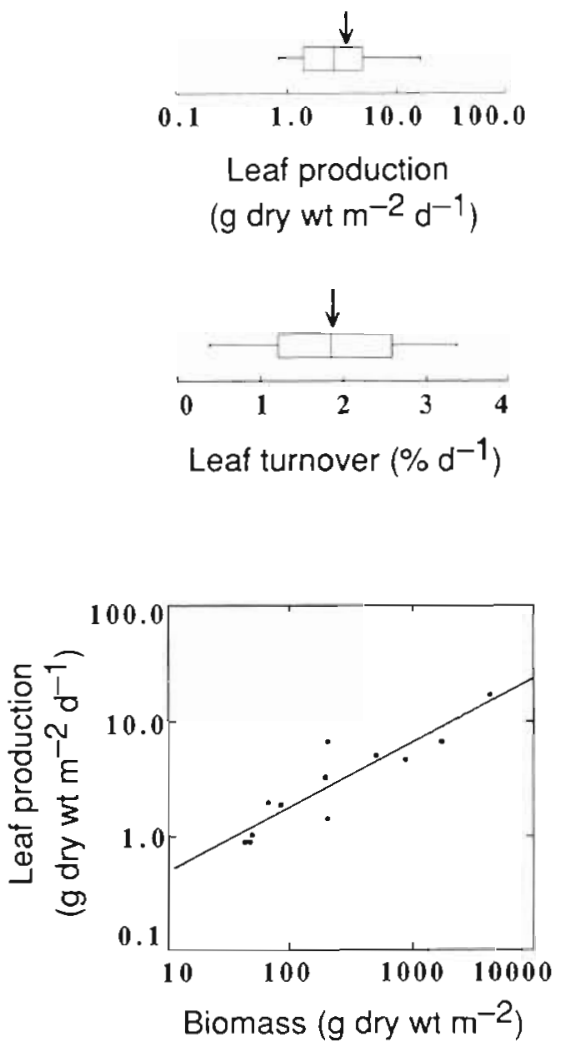

Fig. 4. Thalassia testudium. Box plots summarising available estimates of standing biomass, areal leaf production, and leaf turnover (from data in Table 2), and the relationship between standing biomass and areal leaf production. Boxes encompass the 25 to $75 \%$ quartiles of the data, lines extend to the $95 \%$ $\mathrm{CL}$, and the vertical line in each box indicates the position of the median value. Arrows on box plots indicate the average values encountered in this study (Table 2)

(Spanish Ministry of Education and Science) and funds allocated to M.M. by the UNAM. We thank the staff of the UNAM field station at Puerto Morelos for hospitality and access to their facilities; S. Agustí for assistance during field and laboratory work; and K. Sand-Jensen for kindly providing nutrient analyses and, along with several anonymous reviewers, for useful comments on the manuscript.

\section{LITERATURE CITED}

Barber, B. J, Behrens, P. J. (1985). Effects of elevated ternperature on seasonal in situ leaf productivity of Thalassia testudinum Banks ex König and Syringodium filiforme Kützing. Aquat. Bot. 22: 61-69

Bauersfeld, P., Kifer, R. R., Durrant, N. W., Sykes, J. E. (1969) Nutrient content of turtle grass (Thalassia testudinum) Proc. int. Seaweed Symp. 6: 637-645
Bittaker, H. F., Iverson, R. L. (1976). Thalassia testudinum productivity: a field comparison of measurement methods. Mar. Biol. 37: 39-46

Brouns, J. J. W. M. (1985a). The plastochrone interval method for the study of the productivity of seagrasses; possibilities and limitations. Aquat. Bot. 21: 71-88

Brouns, J. J. W. M. (1985b). A comparison of the annual production and biomass in three monospecific seagrass beds of Thalassia hemprichii (Ehrenb.) Aschers. Aquat. Bot. 23: 149-175

Buesa, R. J. (1972). Producción primaria de las praderas de Thalassia testudinum de la plataforma continental de Cuba. INP, Cuba; Cent. Invest. Pesqueras, Reun. Bal. Trab. CIP 3: 101-143

Buesa, R. (1974). Population and biological data on turtle grass (Thalassia testudinum König, 1805) on the Northwestern Cuban Shelf. Aquaculture 4: 207-226

Burkholder, P. R. L., Burkholder, L. M., Rivero, J. A. (1959). Some chemical constituents of turtle grass, Thalassia testudinum. Bull. Torrey Bot. Club 86: 88-93

Capone, D. G., Penhale, P. A., Oremland, R. S., Taylor, B. F. (1979). Relationship between productivity and $N_{2}(C H)$ fixation in a Thalassia testudinum community. Limnol. Oceanogr. 24: 117-125

Cox, P. A., Tomlinson, P. B. (1988). Pollination ecology of seagrass, Thalassia testudinum (Hydrocharitaceae), in St. Croix. Am. J. Bot. 75: 958-965

Day, J W., Day, R. H., Barreiro, M T., Ley-Lou, F., Madden, C. J. (1982). Primary production in the Laguna de Términos, a tropical estuary in the Southern Gulf of Mexico. Oceanol. Acta, No. Sp., Actes Symposium International sur les lagunes cotieres, SCOR/IABO/ UNESCO, Bordeaux, p. 269-276

den Hartog, C. (1970) The seagrasses of the world. NorthHolland Publ., Amsterdam

Duarte, C. M. (1989). Biomass seasonality and productionbiomass relationships of marine angiosperm communities Mar. Ecol. Prog. Ser. 51: 269-276

Duarte, C. M. (1990). Seagrass nutrient content. Mar Ecol. Prog. Ser. 67: 201-207

Duarte, C. M. (1991). Allometric scaling of seagrass form and productivity. Mar. Ecol. Prog. Ser. 77: 289-300

Duarte, C. M., Sand-Jensen, K. (1990a). Seagrass colonization: patch formation and patch growth in Cymodocea nodosa. Mar. Ecol. Prog. Ser. 65: 193-200

Duarte, C. M., Sand-Jensen, K. (1990b). Seagrass colonization: biomass development and shoot demography in Cymodocea nodosa patches. Mar. Ecol. Prog. Ser. 67: 97-103

Durako, M. J., Moffler, M. D. (1987). Factors affecting the reproductive ecology of Thalassia testudinum (Hydrocharitaceae). Aquat. Bot. 27: 79-95

Eleuterius, L. N. (1987). Seagrass ecology along the coasts of Alabama, Louisiana, and Mississippi. In: Durako, M. J., Phillips, R. C., Lewis, R. R. Ill (eds.) Proc. Symp. subtropical-tropical seagrasses in the southwestern United States. Fla mar. Res. Publs., Florida, 42: 11-20

Erickson, R. O., Michelini, F. J. (1957). The plastochron index. Am. J. Bot. 44: 297-305

Fourqurean, J. W., Zieman, J. C., Powell, G. V. N. (1992). Phosphorus limitation of primary production in Florida Bay: evidence from $C$ : $P$ ratios of the dominant seagrass Thalassia testudinum. Limnol. Oceanogr. 37: 162-171

Gallegos, M. E., Merino, M., Marbá, N., Duarte, C. M. (1992). Flowering of Thalassia testudinum in the Mexican Caribbean: age-dependence and interannual variability. Aquat. Bot. (in press) 
Jones, J. A. (1968). Primary productivaty by the tropical marine turtle grass, Thalassia testudinum König, and its epiphytes. Ph.D. dissertation, Univ. of Miami

Kenworthy, W. J., Thayer, G. W. (1984). Production and decomposition of the roots and rhizomes of seagrasses, Zostera marina and Thalassia testudinum, in temperate and subtropical marine ecosystems. Bull. mar. Sci. 35: $364-379$

Koroleff, F. (1983). Determination of phosphorus. In: Grasshoff, K., Ehrhardt, M., Kremling, K. (eds.) Methods of seawater analysis, 2nd edn. Verlag-Chemie, Nürnberg, p. $125-139$

Lot-Helgueras, A. (1971). Estudios sobre fanerógamas marinas en las cercanías de Veracruz. Ver. An. Inst. Biol. Univ. Autón. México, 42-Ser. Botánica: 1-48

McGraw, J. B., Garbutt, J. (1990a). Demographic growth analysis. Ecology 7(3): 1199-2004

McGraw, J. B., Garbutt, J. (1990b). The analysis of plant growth in ecological evolutionary studies. Trends Ecol. Evol. (TREE) 5(8): 251-4

Merino, M., Otero, L. (1991). Atlas ambiental costero, Puerto Morelos - Quintana Roo. Centro de Investigaciones de Quintana Roo, Chetumal, Mexico

Nugent, R. S., Jordán, E., de la Torre, R. (1978). Investigaciones preliminares de la biomasa de Thalassia testudinum König, en la costa del caribe Mexicano. An. Cen. Cienc. del Mar y Limnol., Univ. Nal. Autón. México 5: $247-254$

Odum, H. T. (1963). Productivity measurements in Texas turtle grass and effects of dredging an intracoastal channel. Publ. Inst. mar. Sci. Texas 9: 48-58

Patriquin, D. (1973). Estimation of growth rate, production and age of the marine angiosperm Thalassia testudinum König. Caribb. J. Sci. 13: 111-123

Pergent, G., Pergent-Martini, C. (1990). Some applications of lepidochronological analysis in the seagrass Posidonia oceanica. Bot. Mar. 33: 299-310

Powell, G. V. N., Kenworthy, W. J., Fourqurean, J. W. (1989). Experimental evidence for nutrient limitation of seagrass

This article was presented by $G$. W. Thayer, Beaufort, N. Carolina, USA growth in a tropical estuary with restricted circulation. Bull. mar. Sci. 44: 324-340

Reyes, E., Merino, M. (1991). Diel dissolved oxygen dynamics and eutrophiedation in a shallow, well-mixed tropical lagoon (Cancún, México). Estuaries 14: 372-381

Short, F. T. (1987). Effects of sediment nutrients on eelgrasses: literature review and mesocosms exqeriment. Aquat. Bot. 27: 41-57

Stevenson, J. C. (1988). Comparative ecology of submerged grass beds in freshwater, estuarine, and marine environments. Limnol. Oceanogr. 33: 223-241

Thorhaug, A., Roessler, M. A. (1977). Seagrass community dynamics in a subtropical estuarine lagoon. Aquaculture 12: $253-277$

Tomasko, D. A., Lapointe, B. E. (1991). Productivity and biomass of Thalassia testudinum as related to water column nutrient availability and epiphyte levels: field observations and experimental studies. Mar. Ecol. Prog. Ser. 75: $9-17$

Williams, S. L. (1987). Competition between the seagrasses Thalassia testudinum and Syringodium foliforme in a Caribbean lagoon. Mar. Ecol. Prog. Ser. 35: 91-98

Williams, S. L. (1988). Thalassia testudinum productivity and grazing by green turtles in a highly disturbed seagrass bed. Mar. Biol. 98: 447-455

Wood, E. J. F., Odum, W. E., Zieman, J. C. (1969). Influence of sea grasses on the productivity of coastal lagoons. In: Ayala-Castañares, A., Phlezer, F. B. (eds.) Lagunas costeras. Mem. Simp. Intern. Lagunas Costeras, UNAMUNESCO, México D.F., 495-502

Zieman, J. C. (1974). Methods for the study of the growth and production of the turtle grass, Thalassia testudinum König. Aquaculture 4: 139-143

Zieman, J. C. (1975). Seasonal variation of turtle grass, Thalassia testudinum Konig, with reference to temperature and salinity effects. Aquat. Bot. 1: 107-123

Zieman, J. C., Fourqurean, J. W., Everson, R. L. (1989). Distribution, abundance, and productivity of seagrasses and macroaigae in Florida Bay. Bull. mar. Sci. 44: 292-311

Manuscript first received: January 15, 1992

Revised version accepted: December 28, 1992 